\title{
The Impact of Credit Risk Management on the Profitability of a Commercial Bank: The Case of BGFI Bank Congo
}

\author{
Ossou Ndzila Fred Nelson ${ }^{1}$ \\ ${ }^{1}$ School of Economics, Shanghai University, China \\ Correspondance: Ossou Ndzila Fred Nelson, School of Economics, Shanghai University, China. Tel: \\ 86-136-7158-9407. E-mail: ossoundzila@ gmail.com
}

Received: January 15, 2020

Accepted: February 6, 2020

Online Published: February 18, 2020

doi:10.5539/ijef.v12n3p21

URL: https://doi.org/10.5539/ijef.v12n3p21

\begin{abstract}
This study examines the impact of credit risk management on the profitability of BGFI Bank Congo, by identifying credit risk indicators and profitability measurement ratios over the period of 2010-2019. The results indicate that profitability is somewhat affected by credit risk management as measured by its credit risk management indicators. The non-performing loan ratio (NPLR), the capital assets ratio (CAR), and the loan loss provision ratio (LLPR) show a negative impact on ROE. These three ratios contribute negatively, while the CAR makes a positive contribution to Return on assets (ROA) and the ratio of client loans and short-term financing (RCLSTF) on return on equity (ROE). Thus, credit risk management has a significant impact on profitability. The study also shows that other selected credit risk management indicators have a significant impact on the Bank's profitability, such as the loan provision ratio (LLPR) and the clean capital adequacy ratio.
\end{abstract}

Keywords: impact, credit risk management, profitability, commercial bank

\section{Introduction}

Over the last decade, rapid innovations in the financial markets and the internationalization of financial flows have almost disrupted the banking landscape. Technological progress and deregulation have created new opportunities for banks and other financial entities, and at the same time greater competitive pressure. In the late 1980s, traditional banking margins began to decline and capital adequacy requirements began to grow up (GREUNING et al., 2004). Banks have reacted vividly and imaginatively to these new challenges as they move into new areas.

There exist several fields in the banking domain which are: commercial bank, domestic and international bank, credit and deposit bank, businesses and individuals, merchant bank, market bank; the different fields have a common factor in all their activities wich is: risk. In a simplified way, the bank is made up of men and capitals, the remuneration of each other flows out from the risk-taking which ends up with gains and losses.

In most of the Word's economies, commercial banks are the most dominant, compared to other financial institutions as the one offering installment loans. As a result, the financial intermediation it plays is vital for developing economies to achieve high economic growth. However, its financial intermediation function gives rise to different types of risks with different magnitudes and causes of profitability, such as:

Credit risk, liquidity risk, market risk, operational risk (Sylvie de Coussergues et al., 2010). In a general context of asymmetric information, the risk is the main concern of commercial banks that have imperfect readability of their customers. Thus, the risk is the most studied factor in the banking sector. Among a plethora of risks, credit risk is the most studied, credit risk is the oldest form of risk in the capital market and is probably the main risk for a bank.

In addition, when banks grant loans, they expect clients to repay the capital amount and the generated interest on a due date. A credit facility is expected to perform well if the payment of capital and interest is not up to date in accordance with the agreed repayment terms.

Credit risk management in commercial banks has, therefore, become more important, not only because of the financial crisis that the sector experienced in 2008 , but also because it is a crucial concept that determines survival, growth and profitability of banks. Given that the provision of credit is one of the main sources of revenue-generating activity in commercial banks, credit risk management affects the profitability of banks. 
Today, without any doubt, we can assert that a poor management and a poor control of credit risk lead to excessive risk of a bank and an impacts on its profitability. This may be the result of a credit decision that generates a risk of default of the institution too high compared to the objectives of the shareholders and other partners of the bank. This may be due to:

- The poor quality of the credit portfolio (share of non-performing loans important);

- Overly optimistic evaluation or undervaluation of credit quality;

- Insufficient credit pricing compare with risk default;

- A non-existent or inadequate credit policy;

- Inadequate identification of bad debts.

Effective and correct management of credit risk on the profitability of a bank can not be overemphasized. The effectiveness of credit risk management improves bank confidence and depositor confidence. Many recent studies from academic circles show that a good credit risk policy is an essential condition for the bank, and the bad credit management and insufficient credit administration are the main causes of the problems encountered in the banking environment.

In this regard, different researchers have examined the impact of credit risk on the profitability of commercial banks in different dimensions. There have been debates and controversies over the analysis and management of credit risks and the profitability of commercial banks. However, some researchers, such as Athanasoglou, et al., 2008, have made extensive studies on this subject and the results obtained have been mixed. Some of them have found that the impact of credit risk management has a positive effect on the profitability of commercial banks (Alshatti et al., 2015) others in contrary have found a negative relationship and suggest that other factors besides the impacts of credit risk management can influence profitability. Specifically (Million et al., 2015) found in a study of commercial banks in Ethiopia between 2003-2004 that there is a significant relationship between commercial bank profitability and credit risk management.

Although several previous studies have been made on the management of credit risk, this question has rarely been covered by researchers from the viewpoint of the Congolese context, in general, and in the context of the Gabonese and French International Bank in Congo Brazzaville (BGFI Bank) in particular which serves as a sample bank over the period 2010-2019. The main objective of this study is to evaluate the impact of credit risk management on the profitability of a commercial bank. It aims at answering the following question:

What is the impact of credit risk management on the profitability of a commercial bank?

From the general objective derive the specific objectives:

- Identify indicators for measuring credit risk management in a commercial bank.

- Identify indicators for measuring the profitability of a bank.

- Understand the impact of credit risk management on the profitability of a commercial bank through these indicators.

This study is only concerned with the identification of the relationship between credit risk management and the profitability of BGFI Bank Congo, other risks to which banks are subjected are not the concern of our research. In addition, this study offers a main interest.

This study is distributed as follows: first, we will present the research methodology and then we will proceed to the statistical description of the data for a better understanding and presentation of the results of the statistical tests for the analysis of the results and recommendations.

\section{Research Methodology}

This section will discuss the method of data collection and processing and the description of the applied regression model; then we will proceed with the research hypotheses and the test of these hypotheses. The study considers two measures of profitability as dependent variables that are the return on assets (ROA), return on equity (ROE).

\section{- Method of data collection and processing}

The data collected consists of annual reports downloaded from the website of BGFI Bank Congo. These data will then be processed in MS Excel 2016, and back to Eviews 9 for descriptive analysis of the variables, this allows us to explain the relationship between the indicators of credit risk and profitability. Finally, the result will be tested again on MS Excel 2016 to confirm the accuracy of the results. 
Our model is composed of the following variables: the ratio of client loans and short-term financing (RCLSTF), the loan loss provision ratio (LLPR) as an independent variable measuring credit risk. Credit risk is also measured by the ratio of non-performing loans (NPLR), the capital adequacy ratio (CAR). To account for unexplained changes in profitability, the error term was included in the model. The models are expressed as follows:

$$
\begin{array}{ll}
\text { Model 1: } & R O A=\beta_{0}+\beta_{1} N P L R+\beta_{2} C A R+\beta_{3} L L P R+\beta_{5} R C L S T F+\varepsilon_{i} \\
\text { Model 2: } & R O E=\beta_{0}+\beta_{1} N P L R+\beta_{2} C A R+\beta_{3} L L P R+\beta_{5} R C L S T F+\varepsilon_{i}
\end{array}
$$

$\beta_{0}$ Constant, $\beta_{1}=\beta_{3}$ Coefficients of independent variables

NPLR: non-performing loan ratio;

CAR: capital assets ratio or capital adequacy capital;

LLPR: loan loss provision ratio;

RCLSTF: The ratio of client loans and short-term financing.

\section{- Return on assets (ROA)}

Return on assets (ROA) is a dependent variable and measures the bank's earnings before interest and taxes against its total net assets. It measures the efficiency in managing banks to generate profits from their scarce resource.

In addition, this ratio is strongly influenced by the credit institution's provisioning policy since the net result incorporates the cost of risk and the assets appear net of the provision in the bank balance sheet. It is used to evaluate the performance of a credit institution. (Sylvie de Goussergues et al., 2010).

\section{- Return on equity (ROE)}

Return on equity (ROE) is a dependent variable and measures the return on shareholders' investment in the bank. ROE has been used as an indicator of profitability in regression analysis because ROE, as well as ROA, has been used extensively in the previous research.

\section{- Non-performing loan ratio (NPLR)}

Non-performing loans (NPL) is an independent variable and it is chosen because it is an indicator of credit risk management. NPLR, in particular, indicates how banks manage their credit risks. Indeed, it defines the proportion of nonperforming losses in relation to the total amount of the loan (Hosna et al., 2009). When the quantity of this ratio increases, it will send a bad message for management at the bank level because it shows a high probability of not recovering funds granted to customers by banks. We expected non-performing loans to have a negative relationship with profitability.

\section{- Capital adequacy ratio (CAR)}

Equation Ratio of Capital (CAR) is also an independent variable. It is chosen because it measures the basis of a bank's financial strength from the point of view of a regulator. This ratio protects depositors from unexpected losses. The capital adequacy ratio consists of the types of financial capital considered to be the most reliable and the most liquid, mainly the equity of the bank, with a good sufficiency ratio.

\section{- The ratio of client loans and short-term financing}

This ratio indicates banks 'ability to withstand deposit withdrawals and banks' willingness to meet loan demand by reducing their holdings of cash. When banks are more liquid, they can reduce the risk of insolvency. This report provides more general information about deposits.

As we previously mentioned, the variables that we will use are CAR, NPLR LLPR, RCLSTF as independent variables and ROE and ROA as dependent variables.

In theory, banks with a good capital ratio have good profitability. A bank with solid capital adequacy is also able to absorb possible loan losses and thus avoids insolvency and bankruptcy.

\section{- Research hypotheses}

From the dependent and independent variables that we have chosen to explain this relationship, we will try to formulate the hypotheses in order to verify whether there really is a relationship between the credit risk and the profitability of a bank. All these elements led to the following hypotheses:

- Hypothesis 1 
Null hypothesis: The ratio of provisions on non-performing loans to a negative impact on profitability (ROE),

Alternative hypothesis: in contrast, the ratio of loans to customers and short-term financing has a positive effect on profitability (ROE).

\section{- Hypothesis 2}

Null hypothesis: There is no correlation between CAR and NPLR and ROE.

Alternative Hypothesis: There is a statistically significant positive relationship between capital adequacy, NPLR, and ROE.

- Hypothesis 3

Is there a significant relationship between capital adequacy, nonperforming loans, and ROA?

$\mathrm{H}_{1}: \beta_{i} \neq 0$ The hypothesis is rejected

$$
H_{0}: \beta_{i}=0
$$

As we said before, CAR and NPLR are indicators of credit risk management and the ROA is one of the profitability indicators. This assumption is used for testing if the relationship exists between the three variables.

\section{- Hypothesis 4}

Is there a statistically significant relationship between LLPR and profitability measured by ROA?

$\mathrm{H}_{1}: \beta_{i} \neq 0$ The hypothesis is rejected

$$
H_{0}: \beta_{i}=0
$$

\section{Result and Empirical Analysis}

In this section, we will present the results of the regression model. We will first analyze the evolution of the balance sheet, receivables, deposits and profitability over the last ten years. Then we will analyze the results and describe the impact of credit risk management on profitability.

\subsection{Analysis of the Evolution of the Profitability of BGFI Bank Congo}

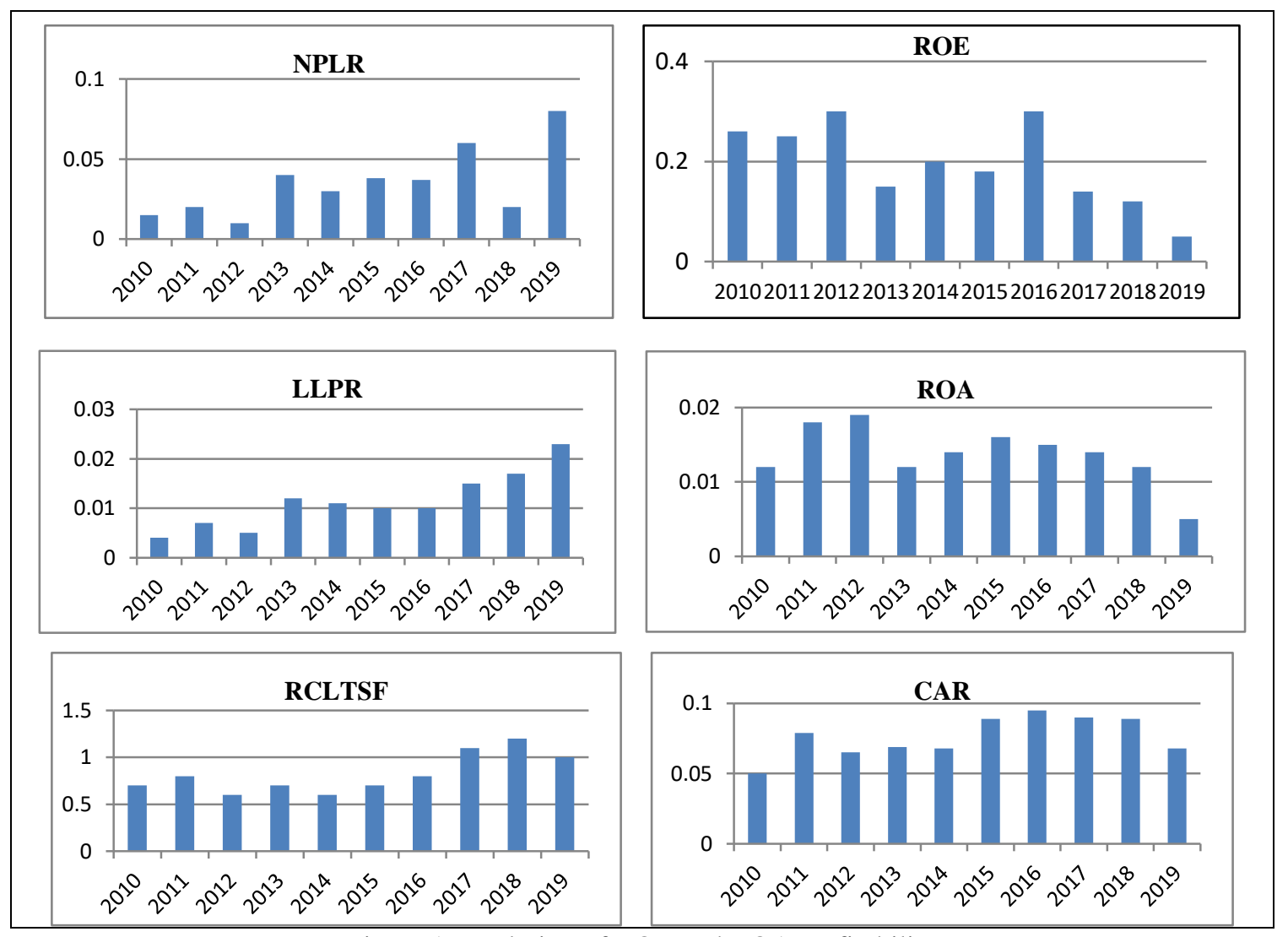

Figure 1. Evolution of ROE and ROA profitability

Source: authored using data from BGFI Bank Congo. 
From 2010 to 2019, the ratio of non-performing loans and the loan loss provision ratio have the same trend. There is a slight increase for each ratio, exempted 2018 for the NPLR a decrease is noted.

As a result, the more the ratio of non-performing loans on total loans and advances decreases, the more the loan loss provision ratio increases, the less profitable the bank is, the ROE and the ROA decreases as the NPLR decreases and LLPR increases.

In addition, the RCLSTF and the CAR also increased slightly between 2010 and 2019, a decrease in 2019is noticed, which explains the decrease in deposits in 2019 or the increase in loans granted to individuals or businesses, which tends to decrease slightly ROE and ROA.

\subsection{Descriptive Analysis of Statistical Data}

The descriptive analysis of the dependent and independent variables is presented in Table 1. The dependent variables are the profitability measured by the ROE and ROA, and the independent variables which are: the non-performing loan ratio, capital adequacy, the ratio of client loans and short-term financing, the loan loss provision ratio. In order to give a brief overview of our data, we present the following table 1 which contains the descriptive statistics of our variables at BGFI Congo from 2010 to 2019.

Table 1. Description of dependent and independent variables

\begin{tabular}{lccccc}
\hline & Mean & Maximum & Minimum & Std, Dev, & Observations \\
\hline ROE & $18.32 \%$ & $27.69 \%$ & $7.91 \%$ & $5.80 \%$ & 10 \\
ROA & $1.35 \%$ & $1.83 \%$ & $0.58 \%$ & $0.36 \%$ & 10 \\
CAR & $7.56 \%$ & $9.21 \%$ & $4.42 \%$ & $1.42 \%$ & 10 \\
NPLR & $2.21 \%$ & $7.75 \%$ & $0.40 \%$ & $2.14 \%$ & 10 \\
LLPR & $1.10 \%$ & $2.40 \%$ & $0.34 \%$ & $0.62 \%$ & 10 \\
RCLSTF & $79.91 \%$ & $115.31 \%$ & $61.71 \%$ & $20.42 \%$ & 10 \\
C & $49.09 \%$ & $60.68 \%$ & $5.77 \%$ & $15.59 \%$ & 10 \\
\hline
\end{tabular}

Source: Calculated by ourselves with Eviews 9 .

The average ROE in the last ten years is $18.32 \%$, with standard deviations of $5.80 \%$. The difference between the minimum value $(7.91 \%)$ and the maximum $(27.69 \%)$ and the standard deviations showed that there was a great variability with the ratio of bad debts. The result, in general, implies that the accumulation of NPLR-that has been claimed as a critical problem of the banking sector in previous studies (Ogbulu et al., 2016).

The result shows that the average value of the bank's profitability (ROA) is $1.35 \%$ indicating that during the period 2010-2019, on average, the total assets of BGFI Congo generated a return of $1.35 \%$. The standard deviation of the ROA is $0.36 \%$, which shows the absence of substantial variation.

The capital adequacy ratio is $7.56 \%$, which is slightly less than or equal to the regulatory requirements of $8 \%$. However, Table 1 shows that the ratio of non-performing loans varies from $0.68 \%$ to $7.75 \%$ with the average and the standard deviation of $2.96 \%$ and $2.212 \%$ respectively, which indicates a high volatility of the bank's ability to manage credit risk.

In addition, BGFI Bank Congo has an average of $1.1 \%$ of the provision for loan losses with a standard deviation of $0.62 \%$. The maximum and minimum values were respectively $2.40 \%$ and $0.34 \%$.

The client loan and short-term financing ratio (RCLSTF) has an average of $79.91 \%$, with a difference of $71.77 \%$. The maximum and minimum values are respectively $115.31 \%$ and $61.71 \%$. This suggests that the bank focuses on lending activities, which is relatively riskier than other options to use depositors' money. The maximum value also raises a surprise on how the bank lends beyond their total deposit and engaged in a high-risk activity.

Tables 2 and 3 are the results of the multi-collinearity test.

Table 2. Correlation matrix for regression $1 \mathrm{ROE}$

\begin{tabular}{lccccc}
\hline & ROE & CAR & NPLR & RPPP & RPCFCT \\
\hline ROE & 1 & & & & \\
CAR & -0.5177 & 1 & & & \\
NPLR & -0.8414 & 0.3373 & 1 & 1 & 1 \\
LLPR & -0.9388 & 0.4242 & 0.8246 & 0.6635 & 1 \\
RCLSTF & -0.6046 & 0.4891 & 0.4512 & & \\
\hline
\end{tabular}

Source: Calculated by ourselves with Eviews 9. 
Table 3. Correlation matrix for regression 2 ROA

\begin{tabular}{lccccc}
\hline & ROA & CAR & NPLR & RPPP & RPCFCT \\
\hline ROA & 1 & & & & \\
CAR & 0.1990 & 1 & & & \\
NPLR & -0.6731 & 0.3373 & 1 & 1 & 1 \\
LLPR & -0.7243 & 0.4242 & 0.8246 & 0.6635 & \\
RCLSTF & -0.3507 & 0.4891 & 0.4512 & & \\
\hline
\end{tabular}

Source: Calculated by ourselves with Eviews 9.

In Tables 2 and 3, we find that the highest correlation between all variables in absolute value is -0.93878 , which is the correlation between LLPR and ROE. This means that a small change in one of the observations or the number of observations leads to a profound change in the estimated values of the coefficients.

The purpose of analyzing the nature of the correlation between the dependent and independent variables is to determine whether the multicollinearity exists or not because of the correlation between the variables. The correlation matrix shown in Tables 2 and 3 provides some insights into the independent variables that are significantly correlated with ROE and ROA dependent variables. The results indicate that the ROE and ROA are significantly negatively correlated with the ratio of non-performing loans, the loan loss provision ratio, and finally the ratio of loans to customers and short-term financing. The result implies that as the value of the ratios increases, profitability will decrease. Unlike the NPLR, LLPR, RCLSTF the clean bottom adequacy ratio is significantly positively correlated with the ROA which means that an increase in the clean bottom adequacy ratio is accompanied by a variation of the ROA. However, CAR is negatively correlated with ROE, which means that ROE decreases as the capital adequacy ratio increases. In addition, the capital adequacy ratio (CAR) is positively correlated with the non-performing loan ratio (NPLR).

\subsection{Heteroscedasticity Test: Breusch-Pagan-Godfrey}

In order to detect heteroscedasticity problems, the Breusch-Pagan test was used in this study.

Table 4. Homoscedasticity test

\begin{tabular}{llll}
\hline Homoscedasticity test with ROE & & & \\
\hline F-statistic & 0.616075 & Prob. F (4,5) & 0.6703 \\
Obs*R-squared & 3.301448 & Prob. Chi-Square (4) & 0.5087 \\
Scaled explained SS & 0.885854 & Prob. Chi-Square (4) & 0.9266 \\
\hline Homoscedasticity test with ROA & & & 0.4312 \\
\hline F-statistic & 1.147351 & Prob. F (4,5) & 0.3100 \\
Obs*R-squared & 4.785913 & Prob. Chi-Square (4) & 0.9344 \\
Scaled explained SS & 0.830217 & Prob. Chi-Square (4) & \\
\hline
\end{tabular}

Source: Calculated by ourselves with Eviews 9.

The probability of the Breusch-Godfrey test is $50.87 \%$ for the ROE and 31\% for ROA which are higher than $5 \%$, all the coefficients of the regression of the residuals squared are not null which means that we reject the H1 hypothesis of heteroscedasticity and suppose the homoscedasticity of the residues.

\section{Discussion of the Results and Recommendations}

\subsection{Discussion of the Results: Regression Model 1 ROE}

In order to answer the research question, we have established four (4) different hypotheses. And to test these hypotheses, we performed two regression analyses. The results of the hypotheses are summarized in the following section.

Table 5. Regression model 1 ROE

\begin{tabular}{lcccc}
\hline Variable & Coefficient & Std. Error & t-Statistic & Prob. \\
\hline CAR & -0.67067 & 0.618664 & -1.08406 & $32.78 \%$ \\
NPLR & -0.55688 & 0.662056 & -0.84114 & $43.9 \%$ \\
LLPR & -6.93873 & 2.628493 & -2.63981 & $4.6 \%$ \\
RCLSTF & 0.01687 & 0.053342 & 0.31626 & $76.46 \%$ \\
C & 0.31324 & 0.044654 & 7.014803 & 0.0009 \\
\hline
\end{tabular}

Source: Calculated by ourselves with Eviews 9. 


$$
\text { ROE }=-0.6706 * \text { CAR }-0.5568 * \text { NPLR }-6.9387 * \text { RPPP }+0.0168 * \text { RPCFCT }+0.3132
$$

R-squared $=0.915363$

Adjusted R-squared $=0.847654$

F-statistic $=13.51902$

As Table 5 shows: The coefficient of determination $\left(\mathrm{R}^{2}\right)$ of Model 1 is $91.53 \%$, which is a good result to show the influence of the explanatory variables (CAR NPLR LLPR and RCLSTF) in the model. In other words, the model-independent variables account for $91.53 \%$ of the variance in BGFI Bank Congo return measured by ROE. The high value of the coefficient shows a significant relationship between profitability and the indicators of credit risk measurement at BGFI Bank Congo. In addition, the F-statistic test is 13.51902 since the probability of zero is attached to the statistic F shows that this null hypothesis (H0) must be rejected.

\section{- Non-performing loan ratio (NPLR)}

Regarding the impact of each independent variable, the results in Table 5 show that the ratio of nonperforming loans to total loans and advances at a negative coefficient (-0.5568). This coefficient has a negative impact on ROE, which means that a unit increases in NPLR will decrease 0.5568 ROE units when the other variables are held constant, but this relationship is not significant at the 5\% threshold. This one responds to the research hypothesis that we have emitted.

\section{- Capital adequacy ratio (CAR)}

According to the results in Table 5, the negative and statistically insignificant impact, the adequacy of capital on return on equity (ROE) determines the bank's risk-taking behavior. This study identifies the statistically insignificant and negative impact of capital adequacy ratio on ROE. Thus, the result is incompatible with the hypothesis developed in this study. Indeed CAR shows a negative impact on ROE in with a coefficient of -0.670665 . This negative sign indicates an inverse relationship between the capital adequacy ratio and the ROE. Thus, this implies that an increase of one unit in the CAR will reduce the ROE by 0.670665 units when the other variables are kept constant. But CAR is not significant at the 5\% threshold. Indeed its probability is 0.3278 which implies that the CAR can predict the ROE with a probability of $67.22 \%$.

In addition, the results in Table 5 indicate the bank's weakness in credit risk management. This is evidenced by the insignificant "capital adequacy ratio" result and the negative ratio of the "nonperforming loan ratio".

The insignificant "capital adequacy ratio" result indicates that the capital adequacy ratio can not be considered as the variable that influences the profitability of BGFI Bank Congo measured by ROE. The study rejects the hypothesis according to which the higher the capital adequacy ratio, the greater is the ability of the bank to lend money, and absorb the resulting losses, each time it generates and earns higher returns because the negative coefficient is insignificant. NPLR, in particular, indicates how banks manage credit risk because it defines the proportion of the amount of impaired loans to the total loan amount. All this evidence supports that BGFI Bank Congo needs to improve its credit risk management.

\section{- The ratio of provision for loss on loan or debt (LLPR)}

The ratio of loan loss provision ratio has a negative effect with ROE, with a coefficient of (-6.938726), and significant at the 5\% threshold. A $100 \%$ increase in provisions will result in a decrease in ROE of $69.38 \%$. Its probability is $4.6 \%$ implying that LLPR can predict ROE with a probability of $95.40 \%$.

\section{- The ratio of client loans and short-term financing (RCLSTF)}

The ratio of client loans and short-term financing (RCLSTF) showed a positive effect of 0.016 . This means that all other variables remain constant, an increase in the RCLSTF unit causes a variation of $1.6 \%$ unit on ROE, but not significant at the 5\% threshold, since its probability is $76.46 \%$ greater than $5 \%$. This indicates that RCLSTF can predict ROE with a low probability of $23.54 \%$. It is recommended to BGFI Bank Congo to strengthen its capacity in credit analysis and loan administration.

4.2 Discussion of the Results: Regression Model 2 ROA

This section analyzes the impact of credit risk management indicators on the profitability of BGFI Bank Congo measured by ROA. 
Table 6. Regression model 2 ROA

\begin{tabular}{lcccc}
\hline Variable & Coefficient & Std. Error & t-Statistic & Prob. \\
\hline CAR & 0.16047 & 0.051389 & 3.122725 & 0.0262 \\
NPLR & -0.03945 & 0.054993 & -0.71727 & 0.5053 \\
LLPR & -0.45638 & 0.218334 & -2.0903 & 0.0909 \\
RCLSTF & -0.0007 & 0.004431 & -0.15145 & 0.8855 \\
C & 0.00806 & 0.003709 & 2.173425 & 0.0818 \\
\hline
\end{tabular}

Source: Calculated by ourselves with Eviews 9.

$$
\mathrm{ROA}=0.1604 * \mathrm{CAR}-0.0394 * \mathrm{NPLR}-0.4563 * \mathrm{RPPP}-0.00067 * \mathrm{RPCFCT}+0.0080
$$

R-squared $=85.23 \%$,

Adjusted R-squared $=73.41 \%$,

F-statistic $=7.211836$,

Prob $($ F-statistic $=0.026258$

Durbin-Watson stat $=1.883188$

As shown in Table 6, the pooled regression result shows that $85.23 \%$ of the systematic variation of the dependent variable (ROA) is explained by the four (4) independent variables (CAR, NPLR, LLPR, RCLSTF). The t-statistic value is significant at the 5\% level for CAR and RPPP, which also indicates that there is a linear relationship between the return on assets and the two independent variables. Durbin Watson's stat of 1.883188 indicates the lack of self-correlation.

Moreover, the F-statistic test of this regression model is 7.211836 which indicates that the null hypothesis that all slope parameters $(\beta o)$ are jointly zero. In the case above, the probability of zero attached to the F statistic shows that this null hypothesis must be rejected even at the level of $1 \%$ of significance.

\section{- Capital adequacy ratio (CAR)}

The result in Table 6 indicates that the capital adequacy ratio is positive and statistically significant. The sign of the coefficient is as usual because theoretically, the adequacy ratio of capital should have a positive relationship with the profitability of a bank. This study supports the hypothesis according to which the capital adequacy ratio has a significant effect on the bank's profitability at the 5\% threshold. This implies that holding other variables constant, a 100\% increase in (CAR) will result in an increase in the bank's profitability of $16.04 \%$ as measured by ROA. CAR can predict ROA with a probability of $97.38 \%$ because it has a probability of $2.62 \%$.

\section{- Non-performing loan ratio (NPLR)}

As expected, there is a strong negative association (-0.0394) between bad loans, ie the ratio of nonperforming loans and the profitability measured by the ROA, but this relationship is not significant. The result is contrary to the findings of Alshatti (2015) who found the positive effect of the ratio of non-performing loans on bank profitability. However, this result is similar to the results of (MILLION et al 2015), (Yuga, 2015) where they found a negative relationship between non-performing loans and bank profitability measured by ROA.

The negative ratio of the "non-performing loan ratio" indicates that there is a higher level of provision for credit losses charged to earnings and ultimately leads to a reduction in return (ROA). Thus, the bank must follow Basel II while managing the credit risk. Basel II compliance means a sound approach to tackling credit risk, ultimately improving profitability.

\section{- Loan loss provision ratio (LLPR)}

The loan loss provision ratio is negatively correlated with ROA, with a coefficient of $(-0.456382)$, which is significant at the $10 \%$ threshold. A $100 \%$ increase in provisions will result in a decrease of the ROA of $45.63 \%$. The result is contrary to the findings of (Million et al., 2015), (Ogboiet al., 2013) and (Kosmidou et al., 2008) who found a positive effect between the loan loss provision ratio and the ROA.

\section{- The ratio of loans to clients and short-term financing (RCLSTF)}

Finally, the ratio of the ratio of loans to customers and the short-term financing which is also negatively correlated with the ROA and significant at the $10 \%$ threshold. An increase of one unit of RPCFCT results in a decrease of $0.07 \%$ of the ROA. In other words, whenever this ratio increases, the bank becomes increasingly risky that the credits granted are equal to or sometimes greater than the amount of the deposit. As a result, the 
bank will experience cash issue which can also make the bank risky.

\section{Conclusion}

In this study, we have on one hand analyzed the impact of credit risk management on the profitability of BGFI Bank Congo. To achieve the objectives of the study, we formulated four hypotheses to test the impact of each of the credit risk management indicators used in this study on each of the two profitability indicators. Two models were therefore formulated to test the credit risk management indicators for each of the two profitability indicators, ROE (return on equity) and total asset return (ROA). The key intention is to check whether the credit risk management indicators have the same significant impact on the return on equity (ROE) and return on total assets (ROA). The results show that the use of the non-performing loan ratio, the loan loss provision ratio to represent credit risk management strategies, has a negative impact on both of the profitability indicators used in this study. The result is not significant at the $5 \%$ threshold with the non-performing loan ratio but significant at the $5 \%$ threshold with the loan loss provision ratio.

On the other hand, the study shows that a capital adequacy ratio (CAR) has a positive and statistically significant impact at the 5\% threshold on the ROA of BGFI Bank Congo. This indicates that the bank should lend more to individuals if it holds a strong capital adequacy. Indeed the funds can be kept in the bank, but this will have a cost and the bank may lose the profit that should be earned if the money has been borrowed...

\section{References}

Alshatti, A. S. (2015). The effect of credit risk management on financial performance of the Jordanian commercial banks. Investment Management and Financial Innovations, 12(1), 338-345.

Athanasoglou, P., Brissimis, S., \& Delis, M. (2008). Bank-Specific, Industry-Specific and Macroeconomic Determinants of Bank Profitability. Journal of International Financial Markets, Institutions and Money, 18(2), 121-136. https://doi.org/10.1016/j.intfin.2006.07.001

Greuning, H. V., \& Sonja, B. B. (2004). Analyse et Gestion du RisqueBancaire: Un cadre de référence pour l'évaluation de la gouvernanced'entreprise et du risque financier édition ESKA (p. 369).

Hosna, A., Bakaeva, M., \&Juanjuan, S. (2009). Credit Risk Management and Profitability in Commercial Banks. Master Degree Project No. 2009:36, Gothenburg: School of Business, Economics and Law, University of Gothenburg. Retrieved from https://gupea.ub.gu.se/handle/2077/20857

Kosmidou, K. (2008). The Determinants of bank's profits in Greece during the period of EU financial intégration. Managérial Finance, 34(3), 146-159. https://doi.org/10.1108/03074350810848036

Million, G., Matewos, K., \& Sujata. (2015). The impact of credit risk on Profitability performance of commercial banks in Ethiopia. African Journal of Business Management, 9(2), 59-66. https://doi.org/10.5897/AJBM2013.7171

Ogboi, C. (2013). Impact of Credit Risk Management and Capital Adequacy on the Financial Performance of Commercial Banks in Nigeria. Journal of Emerging Issues in Economics, Finance and Banking, 2(3).

Ogbulu, O. M., \&Eze, G. (2016). Credit Risk Management and the Performance of Deposit Money Banks in Nigeria: An Error Correction Analysis. Applied Economics and Finance, 3(2). https://doi.org/10.11114/aef.v3i2.1356

Sylvie de C., \& Gautier, B. (2010). Gestion de la banque du diagnostic à la stratégie (6th éd., p. 294).

Yuga, R. B. (2016). Effect of Credit Risk on the Performance of Nepalese Commercial Banks. NRB Economic Review, 42-64.

\section{Copyrights}

Copyright for this article is retained by the author(s), with first publication rights granted to the journal.

This is an open-access article distributed under the terms and conditions of the Creative Commons Attribution license (http://creativecommons.org/licenses/by/4.0/). 